\title{
Concept Mapping to Improve Critical Thinking in Nurses: A Pilot Study
}

\author{
Anna Nguyen ${ }^{1}$, PhD, RN, Diana Blackmon², DNP, RN, Linda Cook ${ }^{3}$, PhD, CNS, CNE \\ ${ }^{1}$ Department Head, Nurse Science, Oklahoma State University, Oklahoma City \\ ${ }^{2}$ Assistant Professor of Nursing, Oklahoma City University, Kramer School of Nursing \\ ${ }^{3}$ Assistant Dean for Students Affairs; Associate Professor of Nursing, Oklahoma City University, Kramer \\ School of Nursing
}

\begin{abstract}
Concept mapping (CM) has been used to help nursing students develop critical thinking skills and improve clinical judgment. CM is being used with greater frequency in health profession education settings to visually represent thought processes and links between variables that affect decision-making and patient outcomes. The objective of this pilot study was to evaluate the effectiveness of CM as a teaching tool to improve critical thinking and clinical decision-making skills of experienced nurses in a sub-acute care setting. Significant differences were found in participants' critical thinking skills following a course involving concept mapping. This study offers staff development educators a new process to improve the critical thinking of experienced nurses.
\end{abstract}

Keywords: Concept Maps; Critical Thinking; Sub-Acute Care; Pilot Study

\section{INTRODUCTION}

Patient outcomes are affected by the caregivers' ability to think critically. Critical thinking is an essential component of nursing practice and is highly valued as an educational outcome in academic settings. The American Philosophical Association [APA] Delphi Report (1990) defined critical thinking as "purposeful, self-regulatory judgment which results in interpretation, analysis, evaluation and inference as well as explanation of the evidence conceptual, methodological, criteriological or contextual considerations upon which that judgment was based" (p. 3 ). According to the APA, the ideal critical thinker is habitually inquisitive, well informed, trustful of reason, openminded, flexible, fair minded in evaluation, honest in facing personal biases, prudent in making judgments, willing to reconsider, clear about issues, orderly in complex matters, diligent in seeking relevant information, reasonable in the selection of criteria, focused in inquiry, and persistent in seeking results which are as precise as the subject and the circumstances of inquiry permit. The purpose of this pilot study was to evaluate the effectiveness of concept mapping as a teaching tool to improve critical thinking skills of nurses in a sub-acute healthcare setting.

\section{BACKGROUND}

Critical thinking is necessary for all nurses; the target population for this pilot study was pediatric nurses employed in rehabilitative and long-term care. Because the number of children with complex medical needs is growing and the demand for high quality healthcare is increasing, it is necessary for pediatric nurses to sharpen critical thinking skills for decision-making. To assist in this process, concept mapping (CM) was tested to promote critical thinking. Concept mapping has been used to help nursing students develop critical thinking skills and improve clinical judgment. Concept map is used in numerous healthcare professional programs including medical, nursing, and pharmaceutical education to foster critical thinking and clinical reasoning (Carr-Lopez, Galal, Vyas, Patel, \& Gnesa, 2014; Daley \& Torre, 2010; Too any, 2008). Although nursing programs prepare their graduates to provide care for a variety of patient populations, caring for children with complex medical needs and children with chronic illnesses is considered a nursing specialty and has limited emphasis. Pediatric patients in long-term care are increasingly presenting with complex medical problems that require nurses to possess higher-level skills to process information and make sound clinical decisions. These patients possess characteristics of patients in acute-care hospitals, rehabilitation centers, and residential care facilities in that they have chronic, stable conditions, but may abruptly deteriorate. Clinical judgment at the bedside is an important factor in providing care for these patients. Nurses are heavily relied upon for their assessment skills, clinical judgment, and critical thinking skills each day to identify normal signs for the patient and to anticipate the direction of change, either deterioration or improvement. Due to

${ }^{1}$ Corresponding Author: nguyena@osuokc.edu 
the limited time available during hospital orientation, it is not feasible to educate nurses on every condition related to this patient population. Thus, it is necessary to optimize learning and development of critical thinking skills to inform clinical decision-making and provide optimal patient care management.

\section{REVIEW OF LITERATURE}

Concept mapping (CM) has been used in a variety of health education settings to help students develop critical thinking (CT) skills and improve clinical judgment (Canasi, Amyot, \& Tia, 2014; Carr-Lopez et al., 2014; D'Antoni, Zipp, \& Cahill, 2010). Concept mapping involves the identification and linkage of critical elements in a specific situation or problem. Relationships are identified in a concept map, as are points of intervention to alter outcomes (Rosen \& Tager, 2014).

Ellerman, Kataoka-Yahiro, and Wong (2006) identify concept mapping as one of the major logic models for teaching nursing process. In their study of 40 students, concept mapping was used in client data collection and client physical assessment. Students were asked to make links and establish relationships between the two data bases in order to formulate nursing diagnoses. Significant differences were found in students' ability to think critically after using concept mapping.

Too any (2008) advocates the use of concept maps both as education and application tools for nursing students. As education tools, concept maps can be used in "...organizing, categorizing, analyzing, evaluating (sic)" data (p. 29). Constructing care plan concept maps illustrate the application of concept mapping for nursing students. According to Too any, this process helps students to make connections with material learned in previous courses and deepens understanding.

Atay and Karabacak (2012) analyzed the effects of care plans prepared using concept maps on the critical thinking disposition of freshman and sophomore students. Students in the control group prepared care plans using the column format while the experimental group prepared care plans using concept maps. Pre- and post-test of the California Critical Thinking Skills Test (CCTST) demonstrated significant greater thinking skills in the experimental group.

The gap in the literature related to concept mapping and critical thinking was in the population of experienced nurses. Concept mapping as a teaching tool in nursing education is relatively new. Few citations are found in the science and education literature before 1990; citations begin in the nursing literature in the mid-1990's. Many nurses in current practice finished their formal nursing education before then. The research question, then, is whether experienced nurses can increase critical thinking skills with a course in concept mapping.

\section{METHOD}

\subsection{Design.}

A quasi-experimental pre- and post-test single group design was used to establish if concept mapping of three core concepts (malnutrition and dehydration, seizure disorders, and acute respiratory issues) would improve critical thinking measured by the California Critical Thinking Skills Test (CCTST). This pilot study took place during the summer months, from June through August.

\subsection{Sample.}

Nurses at a pediatric rehabilitative and long-term care facility were selected as a convenience sample. The nurses graduated from a variety of nursing programs, many from associated degree programs, and some from diploma programs as well as practical nursing programs. Inclusion criteria were broad. All nurses were invited to participate and were eligible after signing informed consent. Nurses who missed more than $50 \%$ of the in-class sessions and did not keep up with the on line activities more than $50 \%$ of the time were excluded from the study. A sample size of 21 was used to provide $80 \%$ statistical power and an alpha error of 0.05 . Twenty-one nurses consented to participate and were eligible to enroll in the program. However, five participants dropped out due to job changes which gave a $80.9 \%$ attrition rate. Seventeen participants completed the project. The study received approval from the Institutional Review Board prior to participant recruitment. Participant data was coded to assure anonymity.

\subsection{Instrument.}

Critical thinking was the outcome variable used to evaluate the effectiveness of concept maps on nurses participated in the study. Nurses completed a paper pencil pre-test and a post-test using the California Critical Thinking Skills Test (CCTST) version 00.2.10. The purpose of the CCTST is to measure cognitive skills, test individuals' ability to analyze, evaluate, infer, and inductively and deductively reasoning when faced with a problem. The validation 
studies of the CCTST were conducted using a case control methodology in college-level institutions in California. The item pool supports the testing of critical thinking skills in persons from grade 3 through doctoral level trainees and the highest level of practicing professionals (CCTST User Manual, 2014). Reliability has been reported for the CCTST as 0.68 to 0.70 using the Kuder-Richardson internal reliability coefficient.

\subsection{Procedure.}

All nurses were given concept mapping exercises and training which lasted approximately one hour per week for 12 weeks. Each week alternated between face-to-face and individual / group email discussions. The instructors were nurses with doctoral degrees. All instructors have experience in teaching concept maps at a baccalaureate nursing program. Seven out of eight face-to-face sessions were taught by the same instructor and all of the email discussions were facilitated by the same instructors. Participants who missed an in-class session were scheduled for a make-up prior to the subsequent week. During the weeks of face-to-face discussions, the content was presented through lectures, brainstorming, class discussions, case studies, collaborative learning groups, and CM group presentation. At these face-to-face sessions, the participants were led through the process of concept mapping using the designated topic for that week. Then, the participants were divided into groups of 2-4 to construct their own maps to practice these skills. A concept map based on a case study was developed every two weeks, for a total of four completed by the end of the training program. See Appendix A for meeting sessions and discussion content.

\section{RESUlts}

Seventeen nurses completed the training program and the CCTST. A two-tailed t-test was used to compare the preand post-levels of critical thinking. Mean pre-test score (18.06) was lower than the mean post-test score $(18.12+$ 5.61). Post-test score was statistically significantly higher than the pre-test score, $t(16)=13.307, p=.000$ (Table $1)$.

The final CCTST score was compared to participant age, experience in nursing, and experience in pediatric nursing. While there was no significant results in the comparison with test score and age (Table 2), experience in nursing and experience in rehabilitative and long-term care in pediatric nursing did have significant effects on CCTST (Table 3 , Table 4).

Table1. Pre- and Post-Critical Thinking Test Scores

\begin{tabular}{|c|c|c|c|c|c|c|}
\hline \\
\hline & \multicolumn{6}{|c|}{\begin{tabular}{|l|} 
One-Sample Test \\
\end{tabular}} \\
\hline & \multirow[b]{2}{*}{$\mathrm{t}$} & \multirow[b]{2}{*}{ df } & \multirow[b]{2}{*}{ Sig. (2-tailed) } & \multirow[b]{2}{*}{ Mean Difference } & \multicolumn{2}{|c|}{$\begin{array}{l}95 \% \text { Confidence Interval of the } \\
\text { Difference }\end{array}$} \\
\hline & & & & & Lower & Upper \\
\hline CT1Overall score & 13.307 & 16 & .000 & 18.05882 & 15.1819 & 20.9357 \\
\hline CT2Overall score & 13.313 & 16 & .000 & 18.11765 & 15.2326 & 21.0026 \\
\hline
\end{tabular}

Table2. Final Critical Thinking Score and Age of Participants

ANOVA

\begin{tabular}{|l|l|l|l|l|l|}
\hline & Sum of Squares & df & Mean Square & F & Sig. \\
\hline Between Groups & 338.598 & 12 & 28.217 & .683 & .726 \\
\hline Within Groups & 165.167 & 4 & 41.292 & & \\
\hline Total & 503.765 & 16 & & & \\
\hline
\end{tabular}

CT2 Overall score and age

Table3. Final Critical Thinking Scores and Number of Years in Nursing of Participants

\begin{tabular}{|c|c|c|c|c|c|c|}
\hline \multicolumn{7}{|l|}{ One-Sample Test } \\
\hline & \multicolumn{6}{|c|}{ Test Value $=0$} \\
\hline & \multirow[b]{2}{*}{$\mathrm{t}$} & \multirow[b]{2}{*}{ df } & \multirow[b]{2}{*}{ Sig. (2-tailed) } & \multirow{2}{*}{$\begin{array}{l}\text { Mean } \\
\text { Difference }\end{array}$} & \multicolumn{2}{|c|}{$\begin{array}{l}\text { 95\% Confidence Interval of the } \\
\text { Difference }\end{array}$} \\
\hline & & & & & Lower & Upper \\
\hline CT2 Overall score & 13.313 & 16 & .000 & 18.11765 & 15.2326 & 21.0026 \\
\hline years in nursing & 3.493 & 16 & \begin{tabular}{|c|}
.003 \\
\end{tabular} & 8.82353 & 3.4680 & 14.1791 \\
\hline
\end{tabular}


American Research Journal of Nursing, Volume 1, Issue 4, August 2015

ISSN 2379-2922

Table4. Final Critical Thinking Scores and Number of Years in Pediatric Nursing

\begin{tabular}{|c|c|c|c|c|c|c|}
\hline \multicolumn{7}{|l|}{\begin{tabular}{|l} 
One-Sample Test \\
\end{tabular}} \\
\hline & \multicolumn{6}{|c|}{ Test Value $=0$} \\
\hline & \multirow[b]{2}{*}{$\mathrm{t}$} & \multirow[b]{2}{*}{ df } & \multirow[b]{2}{*}{ Sig (2-tailed) } & \multirow{2}{*}{$\begin{array}{l}\text { Mean } \\
\text { Difference }\end{array}$} & \multicolumn{2}{|c|}{$\begin{array}{l}\text { 95\% Confidence Interval of the } \\
\text { Difference }\end{array}$} \\
\hline & & & & & \begin{tabular}{|l|} 
Lower \\
\end{tabular} & Upper \\
\hline CT2 Overall score & 13.313 & 16 & .000 & 18.11765 & \begin{tabular}{|l|}
15.2326 \\
\end{tabular} & 21.0026 \\
\hline years at CCT & 4.474 & 16 & .000 & 6.88235 & 3.6210 & 10.1437 \\
\hline
\end{tabular}

VI. DISCUSSION

This is the first study that demonstrates the effect of using concept maps as a teaching tool to improve critical thinking and clinical decision-making skills for experienced nurses in the sub-acute pediatric clinical setting. Our study found that there were significant results from the first CCTST to the second. This data indicates that the intervention of concept mapping was significantly linked to improved critical thinking scores.

The age of the participant was a potential confounding variable. It was reasonable to think that as one aged, one might gain critical thinking skills through the usual trial-and-error method of problem-solving. The age of the nurse, however, did not correlate with CCTST scores.

Variables that did prove to be significant were the number of years worked in the nursing career and the number of years worked at that pediatric facility. This leads one to suppose that an increased length of time spent in focused patient care and problem-solving did lend itself to developing critical thinking skills.

Limitations of this pilot study include small sample size with mainly females and a lack of control group. A total of 157 nurses were eligible, but only 21 participated in this study. This was mainly due to the time of the day classes were offered; nurses who work evening and night shifts were not interested in coming to the classes outside of their scheduled work hours. Adding several class times could increase the number of participants in future studies. Replicating this study on a larger scale would improve the validity of the findings that concept mapping, adapted to pediatric nurses, would improve critical thinking. Replicating this study with a control group that do not receive concept map training would strengthen the study and rule out confounding factor such as maturation of the participants that may have influenced on the outcomes.

\section{CONCLUSION}

Findings of this small pilot study point to the importance of incorporating concept maps as a tool to improve critical thinking in nurses working in a specialty field such as pediatrics with complex health needs. It is a challenge to educate nurses on every aspect of health in children with complex medical needs upon employment at this facility. Concept mapping is a tool to improve critical thinking skills and clinical reasoning with the basic nursing knowledge of pediatrics with special needs.

Critical thinking uses both logic and intuition. Critical thinking in nursing also requires a knowledge base, assessment skills to identify when a patient's condition has changed, the ability to apply clinical reasoning to determine the action to take, and evaluating the expected outcomes. This study showed that concept mapping was an effective tool to foster the development and improvement of critical thinking as concept mapping requires reasoning skills, analysis of multiple relationships and consideration of multiple perspectives. In nursing, synthesis and integration of multiple forms of knowledge are required for effective clinical decision making (Caputi, L., \& Blach, D., 2008). No matter the setting, the increasing complexities of the ever changing healthcare environment and rapid change in the delivery of nursing care demands that nurses master complex information effectively and efficiently, use technology, and skillfully coordinate a variety of health care experiences for their patients.

\section{REFERENCES}

[1] American Philosophical Association (1990). Critical thinking: A statement of expert consensus for purposes of educational assessment and instruction. The Delphi report: Research findings and recommendations prepared for the Committee on Precollege Philosophy. Neward, DW: Author. (ERIC Document Reproduction Service No. ED 315423 ).

[2] Atay, S. \& Karabacak, U. (2012). Care plans using concept maps and their effects on the critical thinking dispositions of nursing students. International Journal of Nursing Practice; 18: 233-239.

[3] Canasi, D. M., Amyot, C., \& Tira, D. (2014). Evaluating meaningful leaning using concept mapping in dental hygiene education. The Journal of Dental Hygiene, 88 (1), 20-29. 
[4] Caputi, L., \& Blach, D., Teaching Nursing Using Concept Mapping (2008), College of DuPage Press

[5] Carr-Lopez, S.; Galal, S.; Vyas, D.; Patel, R.; Gnesa, E. (2014). The utility of concept maps to facilitate higher-level learning in a large classroom setting. American Journal of Pharmaceutical Education, 78(9), 1-7.

[6] CCTST User Manual 2014 Insight Assessment. The California Academic Press. San Jose CA.

[7] Daley, B.; Torre, D. (2010). Concept maps in medical education: An analytical literature review. Medical Education, 44(5), 440-448.

[8] D’Antoni, A. V., Zipp, G. P., Olson, V. G., \& Cahill, T. F. (2010). Does the mind map learning strategy facilitate information retrieval and critical thinking in medical students? Medical Education, 10 (61), 1-11.

[9] Ellermann, C. R., Kataoka-Yahiro M. R., \& Wong, L. C. (2006). Logic models used to enhance critical thinking. Journal of Nursing Education, 45 (6), 220-226

[10] Facione, P.A. (1991). Using the California Critical Thinking Skills Test in research, evaluation, and assessment. Millbrae, CA: California Academic Press.

[11] Facione, P.A., \& Facione, N.C. (1994). The California Critical Thinking Skills Test (CCTST), form A and form B: Test manual. Millbrae, CA: California Academic Press.

[12] Rosen, Y. \& Tager, M. (2014). Making student thinking visible through a concept map in computer-based assessment of critical thinking. Journal of Educational Computing Research, 50 (2), 249-270.

[13] Toofany, S. (2008). Critical thinking among nurses. Nursing Management, 14 (9), 28-31.

\section{Appendix A}

\begin{tabular}{|c|c|c|}
\hline WEEK & CONTENT & LEARNING OUTCOMES \\
\hline 1 (In class) & $\begin{array}{l}\text { - Pre-test using the CCTST } \\
\text { - Introduction to concept map (CM) } \\
\text { - Information on methodology and } \\
\text { construction of CM }\end{array}$ & $\begin{array}{l}\text { - Understand how to use CM theory to develop a concept } \\
\text { care map } \\
\text { - Illustrate details of the individual steps for creating a } \\
\text { concept map }\end{array}$ \\
\hline 2 (In class) & $\begin{array}{l}\text { - Mapping a case study (group work) } \\
-\quad \text { Caring for a child with } \\
\text { malnutrition and dehydration }\end{array}$ & $\begin{array}{l}\text { - Be able to develop a CM that illustrates interrelationships } \\
\text { between medical diagnosis, nursing diagnosis, assessment } \\
\text { data, and treatments in caring for a child with malnutrition } \\
\text { and dehydration }\end{array}$ \\
\hline 3 (On line) & 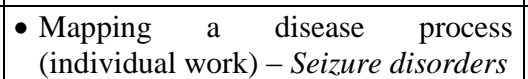 & $\begin{array}{l}\text { - Demonstrate understanding the pathophysiology of } \\
\text { neurological disorders particularly seizure disorders }\end{array}$ \\
\hline 4 (In class) & $\begin{array}{l}\text { - Sharing and reflecting on week } 3 \mathrm{CM} \\
\text { - Discussing a case study - Caring for } \\
\text { a child with a seizure disorder }\end{array}$ & $\begin{array}{l}\text { - Verbalize understanding of the mental model of seizure } \\
\text { disorders } \\
\text { - Be able to communicate with members of the healthcare } \\
\text { team in caring for a child with a seizure disorder }\end{array}$ \\
\hline 5 (On line) & $\begin{array}{l}\text { - Mapping a disease process } \\
\text { (individual work) - Acute respiratory } \\
\text { distress and failure }\end{array}$ & $\begin{array}{l}\text { - Illustrate the ability to recognize the relationships between } \\
\text { medical and nursing care problems including integration of } \\
\text { pathology of acute respiratory issues }\end{array}$ \\
\hline 6 (In class) & $\begin{array}{l}\text { - Sharing and reflecting on week } 5 \mathrm{CM} \\
\text { - Discussing a case study - Caring for } \\
\text { a child with an acute respiratory } \\
\text { issue }\end{array}$ & $\begin{array}{l}\text { - Verbalize understanding of the mental model of acute } \\
\text { respiratory distress versus failure } \\
\text { - Be able to communicate with members of the healthcare } \\
\text { team in caring for a child with an acute respiratory issue }\end{array}$ \\
\hline 7 (On line) & $\begin{array}{l}\text { - Mapping a patient case study } \\
\text { (individual work) - Caring for a } \\
\text { child with an acute asthma attack }\end{array}$ & $\begin{array}{l}\text { - Illustrate the ability to recognize the relationships between } \\
\text { medical and nursing care problems including integration of } \\
\text { pathology, medications, treatments, laboratory and } \\
\text { diagnostic testing in caring for a child with an acute asthma } \\
\text { attack }\end{array}$ \\
\hline 8 (In class) & $\begin{array}{l}\text { - Sharing and reflecting on week } 7 \mathrm{CM} \\
\text { - Discussing a case study - Caring for } \\
\text { a child with complex respiratory } \\
\text { issues }\end{array}$ & $\begin{array}{l}\text { - Be able to communicate with members of the healthcare } \\
\text { team in caring for a child with an acute asthma attack } \\
\text { - Be able to analyze and categorize patient data from the case } \\
\text { study } \\
\text { - Develop goals, outcomes, and interventions in caring for a } \\
\text { child with complex respiratory issues }\end{array}$ \\
\hline 9 (On line) & $\begin{array}{l}\text { - Mapping a patient case study } \\
\text { (individual work) - Caring for a } \\
\text { child with complex medical needs } \\
\text { who is experiencing acute respiratory } \\
\text { distress }\end{array}$ & $\begin{array}{l}\text { - Illustrate the ability to recognize the relationships between } \\
\text { medical and nursing care problems including integration of } \\
\text { pathology, medications, treatments, laboratory and } \\
\text { diagnostic testing in caring for a child with complex } \\
\text { medical needs who is experiencing acute respiratory distress }\end{array}$ \\
\hline 10 (In class) & - Sharing and reflecting on week $9 \mathrm{CM}$ & - Be able to communicate with members of the healthcare \\
\hline
\end{tabular}


American Research Journal of Nursing, Volume 1, Issue 4, August 2015

ISSN 2379-2922

\begin{tabular}{|c|c|c|}
\hline & & $\begin{array}{l}\text { team in caring for a child with complex medical needs who } \\
\text { is experiencing acute respiratory distress }\end{array}$ \\
\hline 11 (In class) & - Pulling it all together & $\begin{array}{l}\text { - Be able to evaluate each patient situations and summarize } \\
\text { clinical impressions in caring for children with complex } \\
\text { health care needs }\end{array}$ \\
\hline 12 (In class) & $\begin{array}{l}\text { - Post-test using the CCTST } \\
\text { - Focus group interview }\end{array}$ & - To gain feedback from participants regarding the training \\
\hline
\end{tabular}

